\title{
Farming System Characterization and Analysis of East Wollega Zone, Oromia, Ethiopia
}

\author{
Kifle Degefa*, Getachew Biru, Galmessa Abebe \\ Bako Agricultural Research Center, Bako, Ethiopia \\ Email address: \\ kifledegu2002@ymail.com (K. Degefa) \\ ${ }^{*}$ Corresponding author \\ To cite this article: \\ Kifle Degefa, Getachew Biru, Galmessa Abebe. Farming System Characterization and Analysis of East Wollega Zone, Oromia, Ethiopia. \\ International Journal of Management and Fuzzy Systems. Vol. 6, No. 2, 2020, pp. 14-28. doi: 10.11648/j.ijmfs.20200602.11
}

Received: May 30, 2020; Accepted: June 15, 2020; Published: August 4, 2020

\begin{abstract}
The study was characterizing and analyze the existing farming system and identify the production and marketing constraints of the East Wollega zone with cross-sectional data of 156 sample respondents. The farming system of the study area is characterized as mixed farming systems with $56.21 \%$ and $28.44 \%$ contribution of crop and livestock, respectively for livelihood activities. The survey result shows that low productivity, shortage/lack of improved varieties, weed infestation, high cost of inputs was identified as main important constraints in crop production while high transaction cost, lack of marketing linkage, low price of output and shortage of market information were reported as main constraints in crop marketing. Disease, feed shortage, grazing land shortage, and lack of improved breed were identified as main important constraints in livestock production whereas high transaction cost, low price output, shortage of market information, unorganized marketing system, and lack of market linkage were reported as main livestock marketing constraints. Besides, soil erosion, soil fertility decline, waterlogging, soil acidity, and termite were reported as the main important constraints in natural resources. To improving crop and livestock productivity access improved varieties and breed, capacitate farmers' awareness on the disease, minimizes transaction cost, focus on the high-value crops, expanding soil and water conservation, strengthening market information and linkage where must the urgent concentration for interventions.
\end{abstract}

Keywords: Crop, Farming System, East Wollega, Livestock and Natural Resource

\section{Introduction}

Small-scale crop-livestock integrated farming systems represent the integration of grain and animal production [1] which is a large fraction of the rural population in the region in general [2] and the East Wollega zone in specific which is a mixed farming system $[3,4]$. Crop production and livestock rearing contribute significantly to the livelihoods of the smallholder farmers $[5,6]$. Except for maize majority of crops grown in the zone are local varieties and the method of production is majorly oxen plow which is hearted from the farmers' ancestors [3]. The substance farmers in the zone usually manage a complex whole farm system of at least several enterprises that are not known with market-oriented crop production and the subsistence production is dominated in the zone [4]. Local cattle are the predominant breeds reared in the area and market-oriented dairy and meat production are rarely practiced in the zone [3].
Crop, livestock, and natural resource production and productivity are constrained by ecological, technical, and economic limitations in the major agro-ecologies of Ethiopia [7]. These constraints call for an identification and analysis farming system that aids to identify the point of intervention in development works to enhance production and productivity of crop, livestock, and natural resources [8].

A farming system is a unique and reasonably stable arrangement of farming enterprises that a household manages according to well-defined practices in response to the physical, biological and socio-economic environment with household goals preferences and resources [9]. It is comprising complex production units involving a diversity of mixed crops and livestock in order to meet the multiple objectives of the household [10] which is similar to the study zone [4].

Understanding the interdependence of the elements of the farming system and maintaining the balance in the complex 
set of farmer's objectives are relevant to outlining promising development strategies for such systems [11]. The classification of developing countries may be varied as an available natural resource base, climate, landscape, farm size, tenure and organization, the dominant pattern of farm activities, and household livelihood [12].

Therefore, this farming system characterized is important to identify and analyzed the intensity of production, diversification of crops, other activities and major constraints of the study area with to characterize and analyze the existing farming system of major agroecologies and identify the production constraints of the farming system for further development and research interventions of the study zone.

\section{Research Methodology}

\subsection{Description of the Study Area}

The study was conducted in East Wollega zone which is one of the zones of Oromia National Regional State that comprises 17 districts. The total land area of the zone is about $14,102.50 \mathrm{~km}^{2}$ which accounts for about $3.88 \%$ of the total area of the National Regional State of Oromia and has 1,199,444 rural populations [3].

East Wollega zone is characterized by three major agroecologies include highland (13\%), midland (57\%), and lowland $(30 \%)$ with hilly, undulating, and rolling topographical features. It's altitude ranges between 1000 and 2798 meters above sea level with the mean annual rainfall ranging between $1400 \mathrm{~mm}$ and $2200 \mathrm{~mm}$. The main rainy season runs from the months of May to September. The soil types are clay and red sandy clay. Tef, barley, wheat, faba bean, sesame, groundnut, field pea, maize, sorghum, finger millet, potato, tomato, hot-pepper, and nug are some major crops grown in the zone [3].

\subsection{Sampling Techniques}

A multi-stage sampling procedure was employed to select representative sample respondents. In the first stage, Diga, Jima Arjo, and Boneya Boshe districts were selected purposively depending on their representativeness on the existing socio-economic, socio-cultural, and agroecological diversities of the targeted population of the zone. On the second stage, the kebeles were stratified based on farmers farming system cluster to capture the existing socio-economic, socio-cultural, and agro-ecological diversities of the targeted population. On the third stage, eight kebeles (two from highland, four from midland and two from lowland) kebeles were selected purposively from farming system cluster with the consultation of experts from each district's based on the existing socio-economic, socio-cultural, and agro-ecological diversities of the targeted population of each district. Finally, 156 sample respondents were selected randomly from strata based on proportional probability size.

\subsection{Types of Data}

Both primary and secondary data were collected and analysed for the study. Secondary data were collected from Zonal Finance and Economic Development Office and Agricultural and Natural Resource Development Office at zone and districts using comprehensive and well-prepared checklists and soft copies of these data were also collected from respective offices. The household interview and Focused Group Discussion (FGD) using PRA tools were undertaken by researchers from different disciplines that include crop, livestock, natural resource, socio-economics, and extension research teams.

Among the primary data collected household demographic features, the socio-economic situation of the household, household's resource endowment, household livelihood activities, households' resource allocation pattern, interaction and relationship between different components of the farming system, access to institutional support services access to market, households' use of modern inputs and farming system constraints of production in the zone.

\subsection{Method of Data Collection}

The primary data were collected from the sampled households and key informants. A focused group discussion was undertaken using PRA tools to collect pre-hand qualitative data. After analysing the qualitative data, the team identified parameters to be quantified and then the team prepared the household survey questionnaire. Finally, a formal survey was undertaken from 156 sample respondents.

\subsection{Methods of Data Analysis}

On spot, qualitative data analysis was made for data collected during focused group discussion and quantitative data were analysed using STATA software and the results are presented in descriptive statistics such as minimum, maximum, mean, standard deviation, frequency, and percentage and pairwise rank analysis were employed based on the type of data.

\section{Results and Discussion}

\subsection{General Respondents}

\subsubsection{Farm Implements and Communication}

Ownership of farm implements is help in Ethiopian agriculture which focused on oxen power and weeding and hoeing led by labors force. The result indicated that about $89.10 \%, 62.20 \%$, and 77.60 of respondents were had ox-plow, sickle, and hoe on average 1.50, 3.50, and 3.20 owned for agricultural activities, respectively. Information technology was more informed and can be used as contact farmers through mobile, radio, and TV. About 50.60\%, 55.80, and $3.20 \%$ of respondents had a radio, mobile, and TV which used as technology information dissemination to farmers (Table 1). These communication assets used as successful information sources for technology innovations [13]. 
Table 1. Farm implements and communication of respondents.

\begin{tabular}{llllllll}
\hline Farm implements & N & \%hhs & Mean & Infrastructures & N & \%hhs & Mean \\
\hline Ox-plough & 139 & 89.10 & $1.50(0.60)$ & Radio & 79 & 50.60 & $1.10(0.20)$ \\
Sickle & 97 & 62.20 & $3.50(3.20)$ & Mobile & 87 & 55.80 & $1.40(1)$ \\
Hoe/Jembe & 121 & 77.60 & $3.20(2.70)$ & Television & 5 & 3.20 & 1 \\
Others & 60 & 38.50 & $2.20(1.30)$ & & & & \\
\hline
\end{tabular}

Numbers in parentheses are standard deviations.

Source: own computation (2017).

\subsubsection{Livelihoods and Income Sources}

Crops remain to be a dominant economic activity and source of livelihood in the three agro-ecologies with $97.14 \%$, $86.08 \%$, and $69.05 \%$ of respondents were participated in highland, midland, and lowland agro-ecologies, respectively. The annual income contribution from crops was $54.55 \%$, $60 \%$, and 62.59 in highland, midland, and lowland agroecologies, respectively following livestock rearing. Opportunities to diversify income from beekeeping and off/non-farm activities were reported by respondents. About
$22.86 \%, 21.52 \%$ and $9.52 \%$ of respondents have participated in beekeeping income-generating activities in highland, midland and lowland agro-ecologies with $12.50 \%, 8.75 \%$, and 5.50\% annual income contribution, respectively. Besides, around $17.14 \%, 2.53 \%$, and $7.14 \%$ of respondents have participated in highland, midland, and lowland agroecologies with $12.50 \%, 40 \%$, and $21 \%$ of annual income contribution, respectively (Table 2). The majority of Ethiopian farmers of incomes were generated from crops and livestock activities $[14,15]$.

Table 2. Livelihood activities and percent of annual income contribution of respondents.

\begin{tabular}{|c|c|c|c|c|c|c|}
\hline \multirow{2}{*}{ Income sources } & \multicolumn{2}{|c|}{ Highland $(n=35)$} & \multicolumn{2}{|c|}{ Midland $(n=79)$} & \multicolumn{2}{|c|}{ Lowland $(n=42)$} \\
\hline & \%hhs & Income $(\%)$ & \%hhs & Income (\%) & \%hhs & Income (\%) \\
\hline Crops & 97.14 & 54.55 & 86.08 & 60 & 69.05 & 62.59 \\
\hline Livestock & 88.57 & 36.67 & 73.42 & 29.56 & 59.52 & 26.96 \\
\hline Beekeeping & 22.86 & 12.50 & 21.52 & 8.75 & 9.52 & 5.50 \\
\hline Off/non-farm activities & 17.14 & 12.50 & 2.53 & 40 & 7.14 & 21 \\
\hline
\end{tabular}

Source: own computation (2017).

\subsubsection{Land Ownership}

Land tenure and how the land under the farmers' control was utilized were observed in the study. All the results in table 3 show that an average of 2.06 hectares of owned cultivated land was allocated for rain-fed system and irrigation systems.

Table 3. Land allocated in hectare for different crops produced by respondents.

\begin{tabular}{|c|c|c|c|c|c|}
\hline Variables $(\mathrm{N}=156)$ & $\mathbf{N}$ & Percent & Min. & Max. & Mean \\
\hline Total own land & 139 & 89.10 & 0.02 & 12 & $2.41(2.21)$ \\
\hline Total own cultivable land & 134 & 85.90 & 0.125 & 11 & $2.06(1.86)$ \\
\hline Total own land allocated for crops (irrigated) & 21 & 13.46 & 0.13 & 1 & $0.37(0.21)$ \\
\hline
\end{tabular}

Source: own computation (2017).

The majority of the respondents were practiced rain-fed system $(81.41 \%)$, an average on 1.75 hectares of land, and only $13.46 \%$ of respondents were practiced irrigation, an average on 0.37 hectares of land operated during the survey period. Sample respondents have practiced irrigation for crop production from lowland and highland farming clusters (Table 3) which similar to [16].

\subsection{Crop Farming System}

\subsubsection{Major Crops Grown and Productivity}

Cropping system of the zone is characterized as no fallow land for crop production because of land shortage in all types of farming system clusters and intercropping is really practiced in the lowland areas largely maize with haricot bean. Crop cultivation in the study area mainly depends on the rain-fed system. Cropping patterns adopted by farmers in the study areas were summarized in table 4 . Maize, tef, finger millet, nug, hot-pepper, and potato were the most important crops in the three farm clusters while wheat, barley, faba bean, and field pea were grown only in highland and midland agro-ecologies. 
Table 4. Major crops grown with their productivity in major Agro-ecology by respondents.

\begin{tabular}{|c|c|c|c|c|c|c|c|c|c|}
\hline \multirow[b]{2}{*}{ Crops } & \multicolumn{3}{|c|}{ Highland $(n=35)$} & \multicolumn{3}{|c|}{ Midland $(n=79)$} & \multicolumn{3}{|c|}{ Lowland $(n=42)$} \\
\hline & $\begin{array}{l}\text { \%hhs } \\
\text { grown }\end{array}$ & Area (ha) & $\begin{array}{l}\text { Yield } \\
\text { (Qt/ha) }\end{array}$ & \%hhs grown & $\begin{array}{l}\text { Area } \\
\text { (ha) }\end{array}$ & $\begin{array}{l}\text { Yield } \\
\text { (Qt/ha) }\end{array}$ & $\begin{array}{l}\text { \%hhs } \\
\text { grown }\end{array}$ & $\begin{array}{l}\text { Area } \\
\text { (ha) }\end{array}$ & $\begin{array}{l}\text { Yield } \\
\text { (Qt/ha) }\end{array}$ \\
\hline Maize & 62.86 & 0.42 & 28.70 & 92.41 & 0.91 & 37.78 & 83.33 & 0.89 & 38.78 \\
\hline Tef & 85.71 & 0.58 & 11.01 & 58.23 & 0.51 & 9.31 & 23.81 & 0.38 & 7.31 \\
\hline Wheat & 60 & 0.56 & 18.70 & 11.39 & 0.24 & 16.69 & - & - & - \\
\hline Finger millet & 22.86 & 0.27 & 16.13 & 20.25 & 0.45 & 17.13 & 21.43 & 0.36 & 19.25 \\
\hline Barley & 60 & 0.41 & 18.25 & 10.13 & 0.17 & 15.23 & - & - & - \\
\hline Faba bean & 14.29 & 0.32 & 10 & 3.80 & 0.25 & 9.76 & - & - & - \\
\hline Field pea & 8.57 & 0.24 & 6.37 & 1.27 & 0.13 & 7.67 & - & - & - \\
\hline Nug & 5.71 & 0.32 & 6.5 & 53.16 & 0.43 & 7.52 & 21.43 & 0.41 & 8.43 \\
\hline Ground nut & - & - & - & 5.06 & 0.45 & 11.12 & 30.95 & 0.23 & 12.21 \\
\hline Sesame & - & - & - & 3.80 & 0.25 & 4.32 & 14.29 & 0.34 & 5.23 \\
\hline Hot-pepper & 5.71 & 0.13 & 11.42 & 11.39 & 0.41 & 12.43 & 16.67 & 0.38 & 15.42 \\
\hline Potato & 37.14 & 0.23 & 113.23 & 11.39 & 0.16 & 107.32 & 4.76 & 0.13 & 67.12 \\
\hline Tomato & - & - & - & 6.33 & 0.13 & 45.67 & 7.14 & 0.13 & 76.23 \\
\hline
\end{tabular}

Source: own computation (2017).

The result indicated some crops like sorghum, sesame, groundnut, and tomato were mostly grown in midland and low land agro-ecologies. These indicated that all major crops were grown in midland agro-ecology (Table 4). In three agroecologies maize and tef were grown by large respondents and covered large land related to the other crops. Besides, wheat and barley crops were grown in highland agro-ecology by the majority of respondents on large coverage of land while sorghum, sorghum, and nug were grown in midland and lowland agro-ecologies. From the result, we concluded that cereal mono-cropping is the major farming practice in all three agro-ecologies.

Analysis of crop yields was done separately at the farming system cluster and overall which expressed in quintal per hectare as summarized in table 4. The yield of sample respondents during the survey period was below the national and regional average [17]. This low yield characterized by poor soil fertility with poor soil management [18, 19], poor agronomic practices and knowledge gap of fertilizers use [20-22], and lack of capital to purchase inputs [23].

\subsubsection{Land Ploughing and Inputs Used of Major crops}

The farming systems of smallholders in East Wollega zone were predominantly annual crop productions by using rainfall with traditional land plowing and planting methods. Land plowing frequency of plots for major crops depending on the nature of crops and soil fertility status. This plowing field management can dramatically affect soil conditions [24]. The majority of farmers plowing their fields ranges of 2-4 times depending on the crop. The planting date ranges from March with potato to August by rain-fed system and September to December by irrigation like potato and tomato crops (Table A1).

Soil fertility decline, the application of fertilizers is essential to ensure good yield is among the major problems that decrease the productivity of crops yields for producers with field management include included planting date [25], control pests and disease, responsive plant and soil [26, 27], and moisture availability [28]. Among the mitigation strategies used for yield boost, the application of inorganic fertilizer (Urea and NPS) was used in the zone (Table A2). The result shows that for all major crops the farmers were used inorganic fertilizer below recommendation. This result consists of [29] which directly affected yields. The producers used low inputs due to purchasing power, poor awareness on recommendation amount, importance, and in all crops apply below recommendation rate except maize seed rate [30]. The application of inorganic fertilizers and seed for maize is close to the recommended which is $100 \mathrm{~kg}$ of NPS and $150-200 \mathrm{~kg}$ of urea in all farming system clusters (Table A2).

\subsubsection{Improved Seed Used by Respondents}

In this situation, different organizations including research institutes provide farmers to adopt a technology (variety) in their fields. The adoption of new technology act to improve households' welfare than local technology [10]. This study explored the adoption gap between improved varieties and planting methods. This implies that the majority of respondents used local varieties with broadcasting planting methods (Table 5). Local variety with traditional planting methods declines crop yield $[31,32]$.

The result shows that, majority of crops grown in the areas dominated by local varieties and broadcasting planting methods (Table 5). Maize, tef, sorghum, finger millet, wheat, and potato crops were used improved varieties partially. Among the maize varieties BH-546, BH-660, BH-661, limu, and shone were widely grown. Comparison across the farming clusters BH-660 and BH-661 were adopted at the highland farming cluster while $\mathrm{BH}-546, \mathrm{BH}-660, \mathrm{BH}-661$, limu, and shone were widely adopted at the midland and lowland farming clusters. Among the tef varieties kena, guduru, and Quncho were adopted and used widely. Finger millet like boneya and addis- 01 varieties were practiced by farmers. 
Table 5. Percentage of respondents used improved technologies.

\begin{tabular}{lllllll}
\hline \multirow{2}{*}{ Crops } & High land (35) & & Midland (79) & & Lowland (42) \\
\cline { 2 - 7 } & $\begin{array}{l}\text { Improved } \\
\text { varieties }\end{array}$ & Row planting & $\begin{array}{l}\text { Improved } \\
\text { varieties }\end{array}$ & Row planting & $\begin{array}{l}\text { Improved } \\
\text { varieties }\end{array}$ & Row planting \\
\hline Maize & 77.27 & 98.21 & 93.15 & 97.96 & 48.57 & 97.78 \\
Tef & 40.00 & $* *$ & 15.22 & 6.52 & 30.00 & 30 \\
Wheat & 33.33 & $* *$ & 22.22 & 44.44 & $*$ & $* *$ \\
Finger millet & $*$ & $* *$ & 12.50 & $* *$ & 33.33 & $*$ \\
Sorghum & $*$ & $* *$ & $*$ & 8.51 & $*$ & 17.14 \\
Field pea & $*$ & 66.67 & $*$ & 100 & $*$ & $*$ \\
Ground nut & $*$ & $* *$ & $*$ & 100 & $*$ & 100 \\
Pepper & $*$ & 100 & 22.22 & 100 & $*$ & 100 \\
Potato & 30.77 & 100 & 6.33 & 100 & $*$ & 100 \\
Tomato & $*$ & $* *$ & & & \\
\hline
\end{tabular}

*is local variety and $* *$ broadcasting method.

Source: own computation (2017).

To understand the adoption of other crops there is an adoption gap and the farmers were used local varieties which characterized by low productivity. These local varieties with traditional planting (broadcasting) result in low yield. This gap of new varieties may be due high price of seed, lack of seed, poor seed quality, and untimely available [33,34].

\subsubsection{Major Weeds for Major Crops and Management Practices}

Weed management can be an enormous significance increase yield of the crop [35]. The dominant weeds frequently observed in crop fields were Guizotia scabra spps,
Bromuss spp, Snowdenia polystarcya, Commelina benghalesis, Oalis, Eleusine indica, Avena fatua, Raphatum spp, and Grass spp were reported as important weeds in the study areas during the survey period (Table 6).

Weed management options exercised by respondents were typically hand weeding and herbicide like 2-4-D. Hand weeding was conducted throughout crop stage ranges of 1-3 times depends on crop types and weed infestation. After 2-4D herbicide application, at least one-time hand weeding was commonly practiced in the study areas (Table 6).

Table 6. Major weeds of major crops and their management practices.

\begin{tabular}{|c|c|c|c|}
\hline Crops & Major weeds & Major control methods & Weeding frequency \\
\hline Maize & $\begin{array}{l}\text { Guizotia, snowden, Bromuss spp and } \\
\text { Commelina }\end{array}$ & Hand weeding & Two to four times hand weeding \\
\hline Teff & $\begin{array}{l}\text { Guizotia, oxalis, Bromuss spp, grass spp and } \\
\text { Commelina }\end{array}$ & $\begin{array}{l}\text { Hand weeding and chemical (2-4-D) } \\
\text { application }\end{array}$ & $\begin{array}{l}\text { Mainly once with chemical and two times } \\
\text { by hand }\end{array}$ \\
\hline Wheat & $\begin{array}{l}\text { Guizotia, Oat (Avena fatua) and Raphatum } \\
\text { spp }\end{array}$ & $\begin{array}{l}\text { Hand weeding and chemical (2-4-D) } \\
\text { application }\end{array}$ & $\begin{array}{l}\text { Mainly one-two with chemical and three } \\
\text { times by hand }\end{array}$ \\
\hline Sorghum & Guizotia, Snowden and Oxalis & Hand weeding & One to three times \\
\hline
\end{tabular}

Source: own computation (2017).

\subsubsection{Major Crop Production Constraints}

An in-depth quantitative analysis was undertaken to understand the constraints that inhibit crop production of the respondents in three farming clusters. The major crops production constraints include low productivity (91.14\%), shortage/lack of improved seed (88.57\%), weed infestation (82.86\%), high cost of improved seed (77.14\%), high cost of fertilizer (71.43\%), pests (disease (60\%) and insect (54.29\%) were the main constraints in the highland farming cluster which ranked ranges of 1-7 ranks (Table 7). These constraints indicate that in the farming clusters inadequate awareness of the technologies and poor management skills which contribute to low productivity and profitability which are consists of [36-38].

Table 7. Major crops production constraints of respondents.

\begin{tabular}{|c|c|c|c|c|c|c|c|c|c|}
\hline \multirow{2}{*}{ Crop production constraints } & \multicolumn{3}{|c|}{ Highland $(n=35)$} & \multicolumn{3}{|c|}{ Midland (n=79) } & \multicolumn{3}{|c|}{ Lowland $(n=42)$} \\
\hline & $\mathbf{N}$ & \%hhs & Rank & $\mathbf{N}$ & \% hhs & Rank & $\mathbf{N}$ & \%hhs & Rank \\
\hline Disease & 21 & 60.00 & 6 & 43 & 54.43 & 7 & 27 & 64.29 & 7 \\
\hline Insects & 19 & 54.29 & 7 & 34 & 43.04 & & 25 & 59.52 & \\
\hline Termite & 12 & 34.29 & & 53 & 67.09 & 4 & 28 & 66.67 & 6 \\
\hline High cost of improved seed & 27 & 77.14 & 4 & 62 & 78.48 & 2 & 32 & 76.19 & 3 \\
\hline High cost of fertilizer & 25 & 71.43 & 5 & 64 & 81.01 & 1 & 35 & 83.33 & 2 \\
\hline Shortage/lack of improved seed & 31 & 88.57 & 2 & 52 & 65.82 & 5 & 29 & 69.05 & 5 \\
\hline Lack of capital & 15 & 42.86 & & 27 & 34.177 & & 22 & 52.38 & \\
\hline
\end{tabular}




\begin{tabular}{|c|c|c|c|c|c|c|c|c|c|}
\hline \multirow{2}{*}{ Crop production constraints } & \multicolumn{2}{|c|}{ Highland $(n=35)$} & \multicolumn{3}{|c|}{ Midland $(n=79)$} & \multicolumn{3}{|c|}{ Lowland $(n=42)$} & \multirow[b]{2}{*}{ Rank } \\
\hline & $\mathbf{N}$ & $\%$ hhs & Rank & $\mathbf{N}$ & $\%$ hhs & Rank & $\mathbf{N}$ & $\%$ hhs & \\
\hline Low productivity & 32 & 91.43 & 1 & 37 & 46.835 & & 19 & 45.24 & \\
\hline Weed infestation & 29 & 82.86 & 3 & 55 & 69.62 & 3 & 31 & 73.81 & 4 \\
\hline Poor soil fertility & 11 & 31.43 & & 51 & 64.56 & 6 & 40 & 95.24 & 1 \\
\hline
\end{tabular}

Source: own computation (2017).

\subsubsection{Major Crops Marketing Constraints}

The measurable analysis was undertaken to understand the constraints that inhibit crop marketing of the respondents in three farming clusters that were identified and ranked in table 8. The major crops marketing constraints include lack marketing linkage $(65.71 \%)$, low price of grain $(62.86 \%)$, high transaction cost (51.43\%), lack of capital $(42.86 \%)$, and shortage of market information (37.14\%) of respondents were reported as main constraints in three farming clusters (Table 8). This result indicates that there are net buyers of crop produced and selling the produce challenges is necessary for the fulfillment of short term needs like quantities, prices and market infrastructure [39].

Table 8. Major crops marketing constraints of respondents.

\begin{tabular}{|c|c|c|c|c|c|c|c|c|c|}
\hline \multirow{2}{*}{ Crops marketing constraints } & \multicolumn{3}{|c|}{ Highland $(n=35)$} & \multicolumn{3}{|c|}{ Midland $(n=79)$} & \multicolumn{3}{|c|}{ Lowland $(n=42)$} \\
\hline & $\mathbf{N}$ & \%hhs & Rank & $\mathbf{N}$ & \%hhs & Rank & $\mathbf{N}$ & $\%$ hhs & Rank \\
\hline Lack of capital & 15 & 42.86 & 4 & 27 & 34.177 & 5 & 22 & 52.38 & 4 \\
\hline Low price of output & 22 & 62.86 & 2 & 59 & 74.684 & 2 & 26 & 61.90 & 2 \\
\hline Shortage of market information & 13 & 37.14 & 5 & 49 & 62.025 & 4 & 18 & 42.86 & 5 \\
\hline Lack of market linkage & 23 & 65.71 & 1 & 72 & 91.139 & 1 & 37 & 88.10 & 1 \\
\hline High transaction cost & 18 & 51.43 & 3 & 54 & 68.354 & 3 & 23 & 54.76 & 3 \\
\hline
\end{tabular}

Source: own computation (2017).

Market access is an opportunity to adopt new technologies which have major implication for household production [40] and food security [41]. In general, access to markets tended to decrease household dependence on any specific resource. It means households with access to markets required less land and livestock for ensuring food security than those without it [42]. Access to output markets has also played a critical role in supporting high and stable economic returns to production, alleviating vulnerabilities to shocks and providing opportunities to buy and sell crops, and access non-farm work [43].

\subsection{Livestock Production Farming System}

\subsubsection{Livestock Ownership}

A high percentage of the population in the survey areas own cows, oxen, heifers, calves, shoats and poultry types of livestock were the major livestock in three farming clusters and summarized in table 9. About $80.00 \%$ with 2.46 TLU herd size and $82.86 \%$ with 2.86 TLU herd sizes cows and oxen rearing highland farming cluster, respectively (Table 9). From total respondents, $72.15 \%$ with 2.70 TLU herd size and $75.95 \%$ with 3.12 TLU herd size cows and oxen rearing midland farming cluster while $59.52 \%$ with 2.24 TLU herd size and $73.81 \%$ with 3.00 TLU herd sizes cows and oxen rearing lowland farming cluster, respectively (Table 9).

Sheep and goats are important as an income source by the farming population. About $80 \%$ with $0.23,44.30 \%$ with 0.23 , and $47.62 \%$ with 0.35 TLU heard the size of shoats owned in highland, midland and lowland farming, respectively (Table 9). Donkeys and horses were used for transportation services. About $31.43 \%, 41.77 \%$, and $28.57 \%$ of respondents were have owned donkey for means transportation service and income generation sources in highland, midland, and lowland farming clusters, respectively (Table 9). Although chicken (local and improved) breeds kept by $60 \%, 60.76 \%$, and $59.52 \%$ of respondents in highland, midland, and lowland farming clusters (Table 9).

Table 9. Household livestock ownership, proportion of owners and herd sizes (TLU)

\begin{tabular}{|c|c|c|c|c|c|c|c|c|c|}
\hline \multirow{2}{*}{ Livestock type } & \multicolumn{3}{|c|}{ Highland $(n=35)$} & \multicolumn{3}{|c|}{ Midland $(n=79)$} & \multicolumn{3}{|c|}{ Lowland $(n=42)$} \\
\hline & $\mathbf{N}$ & \%hhs & Mean & $\mathbf{N}$ & \%hhs & Mean & $\mathbf{N}$ & \%hhs & Mean \\
\hline Cows & $28^{* 3}$ & 80.00 & $2.46(1.55)$ & 57 & 72.15 & $2.70(2.20)$ & 25 & 59.52 & $2.24(1.36)$ \\
\hline Oxen & 29 & 82.86 & $2.86(1.43)$ & 60 & 75.95 & $3.12(1.84)$ & 31 & 73.81 & $3.00(1.84)$ \\
\hline Heifers & 15 & 42.86 & $1.21(0.62)$ & 44 & 55.70 & $1.62(1.60)$ & 19 & 45.24 & $1.58(0.90)$ \\
\hline Calves & 23 & 65.71 & $0.50(0.21)$ & 54 & 68.35 & $0.56(0.36)$ & 20 & 47.62 & $0.57(0.32)$ \\
\hline Sheep and goats & 28 & 80.00 & $0.23(0.27)$ & 35 & 44.30 & $0.23(0.20)$ & 20 & 47.62 & $0.35(0.35)$ \\
\hline Horses & 6 & 17.14 & $1.28(0.45)$ & 11 & 13.92 & $1.27(0.47)$ & 3 & 7.14 & $1.47(0.64)$ \\
\hline Poultry & $21 * 6$ & 60.00 & $0.10(0.03)$ & $48^{* 22}$ & 60.76 & $0.11(0.05)$ & $25^{* 8}$ & 59.52 & $0.12(0.06)$ \\
\hline Total TLU & 33 & 94.29 & $9.66(5.04)$ & 63 & 81.01 & $10.63(7.15)$ & 35 & 83.33 & $9.86(5.44)$ \\
\hline
\end{tabular}

Note: $*=$ Percentage of crossbred breed and numbers in parentheses are standard deviations.

Source: own computation (2017). 
Generally, livestock ownership is regarded as key to rural livelihoods which are sources of power and fertilizer for crop production, supply human food, transportation, income generation sources, and wealth communication [44, 45]. Moreover, the role of oxen availability played in the timely adequate cropland preparation could contribute to increasing food-feed crop production [46]. This integrated croplivestock farming in the study area is often assumed to lead to synergies between crop and livestock production, thereby improving the overall productivity and resilience of agricultural production. Besides, using manure is also an important variable for the rural household's land productivity enhancement by improving soil fertility [47].

\subsubsection{Livestock Feeds and Feeding System}

Livestock producers practiced three grazing systems including own grazing land, crop residues, and communal land and combinations of them (Table 10) which are the same as [48, 49]. Straw (tef, barley, wheat, bean, pea) and Stover of maize and sorghum were extensively used by the majority of respondents due to palatable by livestock and no other feed option for their livestock.

Table 10. Livestock feed sources and feeding system of respondents

\begin{tabular}{|c|c|c|c|c|c|c|}
\hline Common feeds and source & $\mathbf{N}$ & \%hhs & \multicolumn{2}{|c|}{ Improved forage practiced } & $\mathbf{N}$ & \%hhs \\
\hline Own grazing land & 109 & 77.30 & \multirow{2}{*}{ Practiced } & Yes & 41 & 26.30 \\
\hline Crop residues & 114 & 80.90 & & No & 115 & 73.70 \\
\hline Communal land & 45 & 31.90 & \multirow{3}{*}{ Forage types } & Alfalfa and Rhodes & 9 & 22.00 \\
\hline Supplementary feed (Fegullo, etc) & 33 & 23.40 & & Elephant grass & 28 & 68.20 \\
\hline Most common crop residue used & & & & Others & 4 & 9.80 \\
\hline Straw (barley, tef, wheat and finger millet) & 106 & 75.20 & \multirow{3}{*}{$\begin{array}{l}\text { Area used for } \\
\text { forage }\end{array}$} & Homestead & 13 & 31.70 \\
\hline Stover of maize and sorghum & 64 & 45.40 & & On soil conservation & 6 & 14.60 \\
\hline Faba bean and field pea straw & 7 & 5.00 & & On farm & 22 & 53.70 \\
\hline
\end{tabular}

Source: own computation (2017).

About $77.30 \%, 80.90 \%$, and $31.40 \%$ of respondents used own grazing land, crop residues, and communal land, respectively (Table 10). The result revealed that about $26.30 \%$ of respondents have been practicing improved forages including alfalfa, Rhodes, and elephant grass by private and public sectors by respondents during survey period on soil conservation and around the homestead (Table 10).

\subsubsection{Livestock Production Constraints}

Livestock producers were asked to give their perspectives on the most important constraints affecting their livestock farm operations and their responses were summarized in table 11. These livestock production constraints include disease (trypanosomiasis, blackleg, anthrax, pasteurellosis and mastitis lichen, leg and foot and mouth and dermatophytosis), feed shortage, lack of capital, shortage of grazing land, lack of improved breed, water shortage, shortage of veterinary medicine, shortage of awareness in production constraints were reported in three farming clusters which are similar to [50-52].
Disease $(80 \%)$, Shortage of grazing land $(77.14)$, feed shortage (71.43\%), lack of improved breed (65.71\%), and lack of capital $(60 \%)$ were reported as main important constraints and ranked one to five on livestock production in the highland farming cluster (Table 11).

The result shows that shortage of grazing land (84.81\%), disease $(77.22 \%)$, lack of improved breed $(65.82 \%)$, shortage of awareness (59.49\%), and feed shortage (56.96\%) were reported as important constraints and ranked one to five on livestock production in the midland farming cluster. In the lowland farming cluster shortage of grazing land $(83.33 \%)$, disease $(76.19 \%)$, feed shortage $(69.05 \%)$, lack of improved breed $(64.29 \%)$, and shortage of veterinary medicine $(52.38 \%)$ were reported as important constraints and ranked one to five on livestock production in the lowland farming cluster. This result reveals that disease, feed shortage, and lack of improved breed reported as three major constraints in three farming clusters (Table 11).

Table 11. Major livestock production and market constraints of respondents.

\begin{tabular}{|c|c|c|c|c|c|c|c|c|c|}
\hline \multirow{2}{*}{ Livestock marketing constraints } & \multicolumn{3}{|c|}{ Highland $(\mathrm{n}=35)$} & \multicolumn{3}{|c|}{ Midland (n=79) } & \multicolumn{3}{|c|}{ Lowland $(n=42)$} \\
\hline & $\mathbf{N}$ & \%hhs & Rank & $\mathbf{N}$ & \%hhs & Rank & $\mathbf{N}$ & \%hhs & Rank \\
\hline Disease & 28 & 80.00 & 1 & 61 & 77.22 & 2 & 32 & 76.19 & 2 \\
\hline Feed shortage & 25 & 71.43 & 3 & 45 & 56.96 & 5 & 29 & 69.05 & 3 \\
\hline Lack of capital & 21 & 60.00 & 5 & 15 & 18.99 & & 19 & 45.24 & \\
\hline Shortage of grazing land & 27 & 77.14 & 2 & 67 & 84.81 & 1 & 35 & 83.33 & 1 \\
\hline Lack of improved breed & 23 & 65.71 & 4 & 52 & 65.82 & 3 & 27 & 64.29 & 4 \\
\hline Shortage of veterinary medicine & 17 & 48.57 & & 34 & 43.04 & & 22 & 52.38 & 5 \\
\hline Shortage of awareness & 19 & 54.29 & & 47 & 59.49 & 4 & 20 & 47.62 & \\
\hline
\end{tabular}

Source: own computation (2017). 


\subsubsection{Livestock Marketing Constraints}

The livestock marketing constraints include market/demand fluctuation, price fluctuation, low live animal price, shortage of market information, lack of marketing linkage, unorganized marketing system, and high transaction cost in marketing constraints were reported in three farming clusters that are consistent of $[53,54]$.

Table 12. Major livestock marketing constraints of respondents.

\begin{tabular}{|c|c|c|c|c|c|c|c|c|c|}
\hline \multirow{2}{*}{ Livestock marketing constraints } & \multicolumn{3}{|c|}{ Highland $(n=35)$} & \multicolumn{3}{|c|}{ Midland (n=79) } & \multicolumn{3}{|c|}{ Lowland $(n=42)$} \\
\hline & $\mathbf{N}$ & $\%$ hhs & Rank & $\mathbf{N}$ & $\%$ hhs & Rank & $\mathbf{N}$ & \%hhs & Rank \\
\hline Market/demand fluctuation & 18 & 51.43 & 5 & 49 & 62.03 & 4 & 17 & 40.48 & \\
\hline Price fluctuation & 22 & 62.86 & 3 & 29 & 36.71 & & 31 & 73.81 & 3 \\
\hline Low price & 20 & 57.14 & 4 & 32 & 40.51 & & 25 & 59.52 & 5 \\
\hline Shortage of information & 16 & 45.71 & & 57 & 72.15 & 3 & 26 & 61.90 & 4 \\
\hline Lack of market linkage & 11 & 31.43 & & 69 & 87.34 & 1 & 33 & 78.57 & 2 \\
\hline Unorganized marketing system & 31 & 88.57 & 1 & 59 & 74.68 & 2 & 37 & 88.10 & 1 \\
\hline High transaction cost & 26 & 74.29 & 2 & 46 & 58.23 & 5 & 23 & 54.76 & \\
\hline
\end{tabular}

Source: own computation (2017).

In highland farming cluster unorganized marketing system $(88.57 \%)$, high transaction cost $(74.29 \%)$, price fluctuation $(62.86 \%)$, low live animal price, and market/demand fluctuation were reported by respondents as top five livestock marketing constraints (Table 12). In midland farming cluster lack of marketing linkage $(87.34 \%)$, unorganized marketing system (74.68\%), shortage of marketing information $(72.15 \%)$, market/demand fluctuation $(62.03 \%)$, and high transaction cost $(58.23 \%)$ were reported by respondents as livestock marketing constraints and ranked as top five (Table 12). In lowland farming cluster unorganized marketing system $(88.10 \%)$, lack of marketing linkage $(78.57 \%)$, price fluctuation $(73.81 \%)$, shortage of marketing information $(61.90 \%)$, low live animal price $(59.52 \%)$, and high transaction cost $(54.23 \%)$ were reported by respondents as top five livestock marketing constraints (Table 12).

Generally, the result indicated that lack of marketing linkage, shortage of market information, unorganized marketing system, and high transaction costs of the subsistence farmers, which reported as the most important constraint in cattle, shoats, equines, and poultry marketing in three farming clusters. These challenges net buyers of crop produced and selling the products are necessary for the fulfillment of short-term needs like quantities, prices, and market infrastructure [55].

\subsection{Beekeeping Practice}

Beekeeping is a common practice of the rural livelihoods as income generation source and home consumption [56, 57]. Table 13 presented beekeeping practice and major constraint in terms of number and production honey. The result shows that a few percentages of the respondents in the survey areas own traditional types of beehives at $29.49 \%$ with 16.30 numbers per farmer beehives.

Table 13. Beekeeping farm practices of respondents.

\begin{tabular}{|c|c|c|c|c|c|c|}
\hline Bee hives and honey & $\mathbf{N}$ & \%hhs & Mean & Constraints $(n=156)$ & $\mathbf{N}$ & \%hhs \\
\hline Own beehives $(n=156)$ & 49 & 31.4 & & Aunts and wild animal & 34 & 21.79 \\
\hline Traditional beehives $(n=46)$ & 46 & 29.49 & $16.3(12.7)$ & Chemical (herbicide) & 45 & 28.85 \\
\hline Modern beehives $(n=46)$ & 6 & 3.85 & $2.0(0.9)$ & Lack of awareness & 34 & 21.79 \\
\hline Honey harvest (traditional in $\mathrm{kg}$ ) & 46 & 29.49 & $67.1(15.5)$ & Shortage of bee forage & 26 & 16.67 \\
\hline Honey harvest (modern in kg) & 5 & 3.21 & $29.4(17.2$ & Low price of honey & 31 & 19.87 \\
\hline Unit price of honey (kg-1) & 38 & 24.36 & $43.6(13.5)$ & Market fluctuation & 15 & 9.62 \\
\hline
\end{tabular}

Source: own computation (2017).

The five most frequently reported constraints were herbicide $(28.85 \%)$, aunts and wild animals $(21.79 \%)$, lack of awareness $(21.79 \%)$, low price of honey $(19.87 \%)$, and shortage of bee forage (16.67\%), were the most important constraint by bee production and marketing system during the survey period (Table 13) which are consist to [58-60].

\subsection{Natural Resources Practices}

A natural resource is a material that comes from the Earth and in its raw or "natural" state is of value for one reason or another. Natural resource management is taking care of natural resources such as land, water. It's about the long-term implications of actions - thinking about the future and not just about now. The goal is sustainability - balancing social (people and communities), economic (money and jobs), and environmental (land, water, air, and living things) factors [61]. These natural resources divided into agroforestry and soil and water conservation.

\subsubsection{Forestry and Agroforestry Practices}

According to the survey report, forestry and agroforestry of the study areas were both natural, plantation, and its combination of them (Table 14). The result showed that about $82.10 \%$ and $10.40 \%$ of respondents conducted plantation and its combination of them for income generation, soil erosion control, soil improvement, and climate balance 
purpose, respectively (Table 14).

Table 14. Forestry and rainfall pattern for last five years of respondents.

\begin{tabular}{llll}
\hline \multirow{2}{*}{$\begin{array}{l}\text { Plantation and forest practiced in the area } \\
(\mathbf{n}=\mathbf{1 5 6})\end{array}$} & Response & N & \%hhs \\
\cline { 2 - 4 } & Yes & 106 & 68.90 \\
& No & 50 & 31.10 \\
Forest type $(\mathrm{n}=106)$ & Natural* & 8 & 7.5 \\
& Plantation & 87 & 82.10 \\
& Both & 11 & 10.40 \\
\multirow{2}{*}{ Purposes of plantation and natural forest (n=106) } & Income generation & 92 & 86.8 \\
& Soil erosion control & 86 & 81.1 \\
& Soil improvement (legume and shrubs trees) & 87 & 82.1 \\
& Weather balance (temperature) & 43 & 40.6 \\
\hline
\end{tabular}

*natural forest which planted by a group for conservation purpose and different trees grown by nature.

Source: own computation (2017).

Eucalyptus tree was the dominant tree in both districts due to different purposes, especially in terms of income generation following gravilia. The majority of the respondents have conducted plantation around their home (garden), along with the farming land and marginal land for plantation without a strategic plan for plantation.

\subsubsection{Major Forestry and Agroforestry Constraints}

The respondents reported that population increase, shortage of land for plantation, livestock grazing system (open grazing), lack of seedling, and termite infestation are the major forestry constraints [62]. This result shows that about $39.70 \%, 35.30 \%$, and $25.00 \%$ of respondents were reported due to increase population, shortage of land, and open grazing as the main important constraints, respectively. About $19.90 \%$ and $16.70 \%$ of respondents were reported as lack of seedling and termite as important constraints, respectively (Table 15).
Table 15. Major of forestry constraints of respondents.

\begin{tabular}{lll}
\hline Constraints (n=156) & N & \%hhs \\
\hline Over population & 62 & 39.70 \\
Termite infestation & 26 & 16.70 \\
Lack of seedling & 31 & 19.90 \\
Livestock grazing system & 39 & 25.00 \\
\hline
\end{tabular}

Source: own computation (2017).

\subsubsection{Soil and Water Conservation (SWC) Practices}

A natural resource is a common property of social arrangement regulating the preservation, maintains and consumption of common-pool resources like forest, soil, and water was gotten attention from the government to sustainable uses of natural resources [61]. The majority of respondents were practiced different soil and water conservation for different purposes (Table 16) which are similar to [63].

Table 16. Soil and water conservation type and major constraints of respondents.

\begin{tabular}{llll}
\hline Soil and water conservation & & N & \%hhs \\
\hline \multirow{2}{*}{ Practiced (n=156) } & Yes & 125 & 80.10 \\
& No & 31 & 19.90 \\
& Terraces & 56 & 44.80 \\
Soil and water conservation types (n=125) & Check dam & 59 & 47.20 \\
& Grasses & 15 & 12.00 \\
& Multipurpose trees & 25 & 20.00 \\
& Reduce soil erosion & 113 & 90.40 \\
Purposes of soil and water conservation & Increase soil moisture & 53 & 42.40 \\
$(\mathrm{n}=125)$ & Improve soil fertility & 109 & 87.20 \\
\hline
\end{tabular}

Source: own computation (2017).

\subsubsection{Major Soil and Water Conservation Constraints}

The major constraints of natural resources identified by respondents were soil erosion, soil acidity, water-logging, soil fertility decline, and termite [63]. The result shows that about $71.20 \%, 62.20 \%$, and $69.20 \%$ of respondents were reported soil acidity, soil erosion, and poor soil fertility as the main important constraints, respectively. About $33.30 \%$ and $24.40 \%$ of respondents were reported water lack of land and termite as important constraints, respectively. Only $12.38 \%$ of respondents were reported water-logging as a constraint in the study areas (Table 17). To increase smallholder productivity, the government has enacted aspiring plans to develop and extend new high yielder seeds, fertilizers, and natural resource management practices including irrigation $[64,65]$. These show that the households who were using improved seed varieties, inorganic chemical fertilizer, and natural resource management practice was higher compared with other agricultural technologies [66]. 
Table 17. Soil and water conservation type and major constraints of respondents.

\begin{tabular}{llll}
\hline Major constraints $(\mathbf{n = 1 5 6 )}$ & $\mathbf{N}$ & \%hhs \\
\hline Soil erosion & 97 & \\
Termite & 38 & \\
Water logging & 24.40 \\
Soil acidity & 111 & 17.30 \\
Lack of land & 52 & 71.20 \\
Poor soil fertility & 33.30 \\
\hline
\end{tabular}

Source: own computation (2017).

\subsection{Institutional Setting}

\subsubsection{Agricultural Extension Services}

Technology adoption is highly dependent on information access [67]. The type of information to disseminate to farmers and the sources of that information are critical in speeding up the rate of adoption of new technology [68]. Asserting the importance of information sources rather than subsidies are more effective in encouraging fast adoption and boost productivity growth [69].

Table 18. Agricultural Information sources of respondents.

\begin{tabular}{llll}
\hline Description & & N & \%hhs \\
\hline \multirow{2}{*}{ Extension } & Development Agents & 142 & 91.03 \\
service & Research centers & 7 & 4.90 \\
sources & NOGs & 21 & 13.46 \\
Training/ & BoANR & 41 & 26.28 \\
and advice & Livestock rearing & 141 & 90.38 \\
extension & Natural resource & 119 & 62.18 \\
services & Market service & 26 & 76.28 \\
\hline
\end{tabular}

Source: own computation (2017).

The majority of extension service sources were DAs, BoANR, NGOs, and research centers used as mean information sources. The result shows that $91.03 \%$ and $26.28 \%$ of respondents were obtained information or advice services from DAs and BoANR, respectively. Only about $4.90 \%$ of respondents were gained extension service from research centers (Table 18). The extension services were focused on crop production $(90.38 \%)$, livestock rearing $(62.18 \%)$, and natural resource $(76.28 \%)$ managements through training and/advice services (Table 18). The result indicates that all farmers may obtain services on crop production, livestock rearing, and natural resource, and only insufficient information was given on marketing services which are similar to [70]. Besides, the government extension was still the major source of information training and advising farmers. More information on varieties with the full package was received from the DAs through FTC and field visit model farmers.

\subsubsection{Credit Utilization}

In this study, we analyzed the various credit needs of farmers by the districts. It is the most important in technology adoption in terms of input purchase [71, 72]. Results presented in table 19 about $43.40 \%$ of respondents utilized credit for purchasing inputs (fertilizer, seed, and chemical), purchase food items, fattening, and petty trade were important activities attached to credit. The result shows that about $42.90 \%$ and $38.10 \%$ of respondents were used for fattening and purchasing fertilizer for agriculture activities, respectively (Table 19). The result indicates that there is a big gap for credit access among rural farmers with viable options for cheaper credit a subject for further investigation. The majority of respondents were reported collateral (42.86\%) and high-interest rate $(9.52 \%)$ as important constraints (Table 19).

Table 19. Credit utilization and constraints of respondents.

\begin{tabular}{llll}
\hline \multirow{2}{*}{ Credit service access (n=156) } & & Frequency & Percent of households \\
\cline { 3 - 4 } & & $\mathbf{1 4 5}$ & $\mathbf{9 2 . 9 0}$ \\
\hline Credit service received ( $\mathrm{n}=145)$ & & 63 & 43.40 \\
& Purchase fertilizer & 24 & 38.10 \\
Purpose of credit (n=63) & Purchase food items (grain and others) & 6 & 9.50 \\
& Petty trade & 7 & 11.10 \\
& Buy livestock (fattening, others) & 27 & 42.90 \\
& Repayment time & 16 & 25.40 \\
Major constraints (n=63) & High interest & 27 & 42.90 \\
& Collateral & 47 & 74.60 \\
\hline
\end{tabular}

Source: own computation (2017).

\subsubsection{Market Access}

Market access is critical in the economic transformation of rural livelihoods. Improving market linkages along the value chain of major crops increase the opportunities and choices of rural farmers and reduce fluctuations between household consumption and income [36, 37]. Efficient integrated value chains, access to markets and other infrastructure help reduce transaction costs thus raising incomes of the rural poor [38].

Farmer on average access market place 1.80 with average 
walks of 188.10 minutes (Table A3). The main mode of transport commonly used for the commodity was on footwalking, donkeys, horses, carts, and cars. About $80.10 \%$ and $28.20 \%$ of respondents used walking (foot) and a donkey for transportation service, respectively. Using these transport modes farmers preferred cooperatives, small traders, and collectors to sell their products.

Information flow reduces market imperfections with choices for the type of market of farmers to sell their products [73]. Regarding market information access about $65.40 \%$ of respondents were accessed market information before selling their products. The main sources of this market information were extension office (DAs), traders, neighbor farmers, visit the market place, cooperatives, and radio (Table A3). The result shows that about $63.81 \%$ and $62.86 \%$ of respondents were obtained information from neighbor farmers and traders, respectively. About $33.03 \%$ and $30.40 \%$ of respondents have gained information by visiting the market before supply their grain to the market and DAs, respectively and these information sources were preferable by respondents.

\section{Conclusion and Recommendations}

A mixed farming system in the study zone is important in rural smallholder farmers. In all crop types produced in the districts average productivity per hectare is below national average productivity due to different constraints. This low productivity comes due to poor soil fertility management, low inputs use, poor knowledge of farmers on-field management, poor weed management, old varieties with old planting methods. Majority of farmers were suffering by pests (diseases and insects), high cost of inputs (seed and fertilized), shortage of land, weed infestation, shortage or lack of improved varieties, poor soil fertility and termite as major crop production constraints while high transaction cost, low price output, shortage of market information and lack of market linkage were also reported as major crop marketing constraints.

Livestock production is also the most important for different purposes including sources of food (milk, meat, and a byproduct of milk), draught power, transportation service, source of income generation (sale life and byproduct), and manure production for soil fertility improvement. In the livestock management practices, feed resources commonly used in the study areas were primarily natural pasture (communal and own grazing), crop residues, and purchased supplementary feed. Improved forage crop was practiced in the study areas by limited respondents during the survey period. The small number of farmers were practicing traditional beekeeping and herbicides, shortage of bee forage, aunts and wild, price fluctuation, and shortage of bee were identified as major bee constraints.

The major problems of livestock production were disease and parasite (Trypanosomiasis, pasteurellosis, mastitis, anthrax, blackleg, mouth and foot, lichen and lamp skin), shortage of grazing land, shortage of feed, lack of improved breeds, shortage of veterinary medicine and shortage of awareness while high transaction cost, market price/demand fluctuation, lack of market information, unorganized marketing system, and lack of market linkage.

A large number of tree species were observed in the natural forest found scattered on farmlands, garden areas as live fences and marginal land as a source of income generation, control soil erosion, and soil fertility improvement. The major constraints of natural resources which accountable for productivity, decreasing were soil erosion, termite attack, soil acidity, soil fertility decline, water-logging, and lack of sustainable land management caused by over-cultivation, overgrazing, and deforestation. Finally, the following recommendations need more attention from responsible bodies are: (1) enhance production and productivity of crops supply improved inputs, capacitates farmers' awareness on inputs recommendation, field management including integrated pest management (IPM) to control pests and strengthen marketing linkage; (2) access improved breed, improved forage, livestock management, methods of control disease infection and improving marketing linkage; and (3) expanding natural resource conservation and more awareness on use physical and biological soil conservation more critical for soil improvement and increase productivity.

\section{Appendix}

Table A1. Crop land frequency ploughing and planting times of respondents.

\begin{tabular}{|c|c|c|c|c|c|c|c|}
\hline \multirow{3}{*}{ Crops } & \multicolumn{4}{|c|}{ High land $(n=35)$} & \multicolumn{3}{|c|}{ Midland $(n=79)$} \\
\hline & \multicolumn{3}{|c|}{ Ploughing frequency } & \multirow{2}{*}{ Planting (sowing) time } & \multicolumn{3}{|c|}{ Ploughing frequency } \\
\hline & Min. & Max. & Mean & & Min. & Max. & Mean \\
\hline Maize & 2 & 4 & 3.28 & April-May & 1 & 5 & 3.58 \\
\hline Tef & 3 & 5 & 4.00 & Last June- $1^{\text {st }}$ August & 2 & 6 & 4.33 \\
\hline Wheat & 3 & 6 & 4.29 & Last June- $1^{\text {st }}$ August & 4 & 5 & 4.56 \\
\hline Millet & 2 & 4 & 3.38 & Last May-June & 2 & 5 & 3.38 \\
\hline Barley & 2 & 4 & 3.05 & May- $1^{\text {st }}$ June & 2 & 4 & 3.13 \\
\hline Sorghum & & & & & 1 & 4 & 2.15 \\
\hline Bean & 2 & 3 & 2.33 & Last June- $1^{\text {st }}$ July & 2 & 3 & 2.67 \\
\hline Pea & 2 & 3 & 2.45 & Last June- $1^{\text {st } J u l y ~}$ & 2 & 3 & 2.54 \\
\hline
\end{tabular}




\begin{tabular}{|c|c|c|c|c|c|c|c|}
\hline \multirow{3}{*}{ Crops } & \multicolumn{4}{|c|}{ High land $(n=35)$} & \multicolumn{3}{|c|}{ Midland (n=79) } \\
\hline & \multicolumn{3}{|c|}{ Ploughing frequency } & \multirow{2}{*}{ Planting (sowing) time } & \multicolumn{3}{|c|}{ Ploughing frequency } \\
\hline & Min. & Max. & Mean & & Min. & Max. & Mean \\
\hline Nug & 2 & 3 & 2.5 & June-July & 1 & 3 & 2.75 \\
\hline $\mathrm{G} /$ nut & & & & & 2 & 2 & 2.00 \\
\hline Sesame & & & & & 2 & 3 & 2.23 \\
\hline Pepper & & & & & 4 & 5 & 4.50 \\
\hline Potato & 2 & 5 & 3.50 & April & 1 & 5 & 3.00 \\
\hline Tomato & & & & & 2 & 5 & 3.65 \\
\hline
\end{tabular}

Table A1. Continued.

\begin{tabular}{|c|c|c|c|c|c|}
\hline \multirow{3}{*}{ Crops } & \multirow{3}{*}{$\begin{array}{l}\text { Midland ( } \mathrm{n}=79 \text { ) } \\
\text { Planting (sowing) time }\end{array}$} & \multicolumn{4}{|c|}{ Lowland $(n=42)$} \\
\hline & & \multicolumn{3}{|c|}{ Ploughing frequency } & \multirow{2}{*}{ Planting (sowing) time } \\
\hline & & Min. & Max. & Mean & \\
\hline Maize & May- $1^{\text {st }}$ June & 2 & 5 & 2.83 & May \\
\hline Tef & Last Jun-July & 3 & 6 & 3.70 & July- $1^{\text {st }}$ August \\
\hline Wheat & Last Jun- $1^{\text {st }}$ Aug & & & & \\
\hline Millet & Jun- $1^{\text {st }}$ July & 2 & 4 & 2.78 & June-July \\
\hline Barley & May- $1^{\text {st }}$ June & & & & \\
\hline Sorghum & Last March-May & 1 & 4 & 1.80 & Last March-May \\
\hline Bean & June-July & & & & \\
\hline Pea & June-July & & & & \\
\hline Nug & June-July & 1 & 4 & 2.22 & June-July \\
\hline $\mathrm{G} /$ nut & May-June & 2 & 3 & 2.14 & May-June \\
\hline Sesame & May- $1^{\text {st June }}$ & 1 & 4 & 2.17 & May- $1^{\text {st }}$ June \\
\hline Pepper & May- $1^{\text {st }}$ June & 2 & 4 & 2.50 & May- $1^{\text {st }}$ June \\
\hline Potato & March \& Sept.-Nov. & 2 & 4 & 2.87 & April \\
\hline Tomato & November-December & 3 & 4 & 3.12 & November-December \\
\hline
\end{tabular}

Source: own computation (2017).

Table A2. Major Crops with their inorganic fertilizers and seed rate used of respondents.

\begin{tabular}{|c|c|c|c|c|c|c|c|c|c|}
\hline & \multicolumn{3}{|c|}{ Highland $(n=35)$} & \multicolumn{6}{|c|}{ Midland (n=79) } \\
\hline & $\%$ hhs & Urea (\%) & Rate-kg/ha & $\%$ hhs & Urea (\%) & Rate-kg/ha & NPS (\%) & Rate-kg/ha & Seed-kg/ha \\
\hline Maize & 62.86 & 72.73 & $125 \mathrm{~s}$ & 92.41 & 83.56 & 124 & 83.56 & 94 & 24.67 \\
\hline Tef & 85.71 & 40 & 30 & 58.23 & 45.65 & 36 & 60.87 & 37 & 33.40 \\
\hline Wheat & 60 & 57.14 & 34 & 11.39 & 77.78 & 25 & 88.89 & 63 & 110 \\
\hline Barley & 60 & 33.33 & 40 & 10.13 & 25 & 50 & 37.5 & 50 & 148.75 \\
\hline Sorghum & - & - & - & 59.494 & 0 & 0 & 6.383 & 50 & 14.87 \\
\hline Millet & 22.86 & 12.5 & 50 & 20.25 & 31.25 & 41 & 37.50 & 63 & 20.31 \\
\hline Pepper & 5.71 & 5.71 & 50 & 6.33 & 60 & 50 & 60 & 100 & $*$ \\
\hline Maize & 83.56 & 94 & 24.67 & 83.33 & 57.14 & 111 & 57.14 & 92 & 24.31 \\
\hline Tef & 60.87 & 37 & 33.40 & 23.81 & 20 & 50 & 20 & 50 & 33.40 \\
\hline Wheat & 88.89 & 63 & 110 & - & - & - & - & - & - \\
\hline Barley & 37.5 & 50 & 148.75 & - & - & - & - & - & - \\
\hline Sorghum & 6.383 & 50 & 14.87 & 83.333 & 0 & 0 & 5.714 & 50 & 14.81 \\
\hline Millet & 37.50 & 63 & 20.31 & 21.43 & 11.11 & 25 & 11.11 & 50 & 20.31 \\
\hline Pepper & 60 & 100 & * & 14.29 & 50 & 50 & 50 & 50 & * \\
\hline
\end{tabular}

$*=$ not estimated by farmers.

Table A3. Marketing access and mode transportation of respondents.

\begin{tabular}{|c|c|c|c|c|c|c|c|}
\hline \multicolumn{2}{|l|}{ Variables } & Mean & Std. Dev. & \multicolumn{2}{|c|}{ Market information sources and preferable } & $\mathbf{N}$ & $\%$ of hhs \\
\hline \multicolumn{2}{|c|}{ Market access in the area } & 1.80 & 0.80 & \multicolumn{2}{|c|}{ Information access $(\mathrm{n}=156)$} & 102 & 65.40 \\
\hline \multicolumn{2}{|c|}{ Distance to market (mins) } & 188.10 & 114.60 & \multirow{7}{*}{ Information sources } & Das & 31 & 30.40 \\
\hline \multicolumn{2}{|c|}{ Sample $(n=156)$} & $\mathrm{N}$ & $\%$ & & Traders & 7 & 6.90 \\
\hline \multirow{5}{*}{$\begin{array}{l}\text { Main mode of } \\
\text { transport }(\mathrm{n}=156)\end{array}$} & Foot & 125 & 80.10 & & Neighbor farmers & 16 & 15.70 \\
\hline & Car & 27 & 17.30 & & Visit market & 34 & 33.30 \\
\hline & Donkey & 44 & 28.20 & & Radio & 6 & 5.90 \\
\hline & Horse & 23 & 14.70 & & Cooperatives & 8 & 7.80 \\
\hline & Cart & 33 & 21.20 & & & & \\
\hline
\end{tabular}

Source: own computation (2017). 


\section{References}

[1] Asrat, G. A, Yoseph, M. G., and Habtemariam, K. (2018). Integrating crop and livestock in smallholder production systems for food security and poverty reduction in subSaharan Africa. African Journal of Agricultural Research; 13 (25): 1272-1282.

[2] Belay, D., Azage, T., and Hegde, B. P. (2012). Smallholder Livestock Production System in Dandi District, Oromia Regional State, Central Ethiopia. Global Veterinaria; 8 (5): 472-479.

[3] EWZFDOS (East Wollega Zone Finance Development Office and Socio-economics, (2018). Zonal Abstract Report. Nekemte.

[4] Kindu, A., Duncan, A., Valbuena, D., Gérard, B., Dagnachew, L., Mesfin, B., and Gedion J. (2014). Intensification of croplivestock farming system in East Africa: A comparison on selected sites in the highlands of Ethiopia and Kenya, In B. Vanlauwe et al. (eds.), Challenges and Opportunities for Agricultural Intensification of the Humid Highland Systems of Sub-Saharan Africa. Springer International Publishing Switzerland, XII, 404.

[5] Moraine, M., Duru, M., Nicholas, P, Leterme, P., and Therond, O. (2014). Farming system design for innovative croplivestock integration in Europe. Animal., 8 (8): 1204-2017.

[6] Asante, B. O., Villano, R. A., Patrick, I. W., and Battese, G. E. (2017). Determinants of farm diversification in integrated croplivestock farming systems in Ghana. Renew Agric Food Syst.

[7] Mesay, Y., Bedada, B., and Teklemedihin, T. (2013). Enhancing the productivity of livestock production in highland of Ethiopia: Implication for improved on - farm feeding strategies and utilization. International Journal of Livestock Production; 1 (1): 015-029.

[8] Alemayehu, S., Dorosh, P., and Sinafikeh A. (2011). Crop production in Ethiopia: regional patterns and trends. International Food Policy Research Institute, Ethiopia Strategy Support Program II (ESSP II), Working Paper No. 16.

[9] Garnett, T., Appleby, M. C., Balmford, A., Bateman, I. J., Benton, T. G., Bloomer, P., Burlingame, B., Dawkins, M., Dolan, L., Fraser, D., Herrero, M., Hoffmann, I., Smith, P., Thornton, P. K., Toulmin C., Vermeulen S. J., and Godfray H. C. J. (2013). Sustainable Intensification in Agriculture: Premises and Policies. Science; 341 (6141): 33-34.

[10] Dennis, G., John, D., and Jean-Mark, B. (2012). Understanding African Farming Systems Science and Policy Implications. Food security in Africa: Bridging Research and practice Sydney.

[11] FAO, (2016). FAOSTAT. Retrieved 9 August 2016 from http://faostat3.fao.org/browse/R/RL/E.

[12] Dixon, J., Gulliver, A., and Gibbon, D. (2001). Farming systems and poverty: Improving farmers' livelihoods in a changing world. FAO, Rome.

[13] World Bank and AfDB, (2017). The Africa Competitiveness Report 2011. World Economic Forum, Geneva.

[14] Efa, G. T. and Bizualem, A. G. (2017). Sources of Income
Inequality among Farm Households in Ethiopia. Using Gini Coefficient Approach. American Based Research Journal, 6 (8).

[15] Etea, B. G., Zhou, D., Abebe, K. A., and Sedebo, D. A. (2019) Household Income Diversification and Food Security: Evidence from Rural and Semi-Urban Areas in Ethiopia. Sustainability, 11: 3232.

[16] Bereket, K. (2008). Land Reform, Distribution of Land and Institutions in Rural Ethiopia: Analysis of Inequality with Dirty Data. Journal of African Economies; 17 (4): 550-577.

[17] CSA (Central Statistical Agency), 2018. National Statistics (Abstract). Addis Ababa.

[18] Smalling, E. M. A., Lesschen, J. P., Beek, C. L., Jager, D. A., Stoorvogel, J. J., Batjes, N. H. and Fresco, L. O. (2012). Where do we stand 20 years after the assessment of soil nutrient balances in Sub-Saharan Africa, 499-537 in World soil resources and food security/, Lal R., Stewart B. A., Padstow, Great Britain: CRC Press (Advances in Soil Science).

[19] Fischer, T., Byerlee, D., and Edmeades, G. O. (2014). Crop yields and global food security: will yield increase continue to feed the world. ACIAR Monograph. ACIAR, Canberra.

[20] Cavane, E. (2007). Farmers' attitudes and adoption of improved maize varieties and chemical fertilizers in the Manica District, Mozambique. PhD. Dissertation. Michigan State University.

[21] Tewodros, A., and Tefaye, A. (2017). Agricultural Knowledge and Technology Transfer Systems in the Southern Ethiopia. African Journal of Agricultural Research; 13 (14): 682-690.

[22] Roxburgh, C. W. and Rodriguez D., (2016). Ex-ante analysis of opportunities for the sustainable intensification of maize production in Mozambique. Agricultural Systems; 142: 9-22.

[23] Jayne, T. S., Mather, D., and Mghenyi, E. (2010). Principal Challenges confronting household agriculture in Sub-Saharan Africa. World Development; 38, 1384-1398.

[24] Hörbe, T. A. N., Amado, T. J. C., Ferreira, A. O., and Alba P. J. (2013). Optimization of corn plant population according to management zones in Southern Brazil. Precision Agriculture; 14: $450-465$.

[25] Pratley, J. E. ed. (2003). Principles of field crop production, 4th ed. Oxford University Press, Melbourne.

[26] Tittonell, P., Leffelaar, P. A., Vanlauwe, B., van Wijk, M. T. and Giller, K. E. (2006). Exploring diversity of crop and soil management within household African farms: A dynamic model for simulation of $\mathrm{N}$ balances and use efficiencies at field scale. Agricultural Systems; 91: 71-101.

[27] Hirel, B., Tétu, T., Lea, P. J., and Dubois, F. (2011). Improving nitrogen use efficiency in crops for sustainable agriculture. Sustainability, 3: 1452-1485.

[28] Cassman, K. G., Dobermann, A., and Walters, D. T. (2002). Agroecosystems, nitrogen-use efficiency, and nitrogen management. Ambio, 31: 132-140.

[29] Dimes, J., Rodriguez, D., and Potgieter, P. (2015). Raising productivity of maize-based cropping systems in eastern and southern Africa: Step-wise intensification options, 93-110 in 'Crop physiology', ed. by V. O. Sadras and D. Calderini. Academic Press, Oxford. 
[30] Kifle, D., Getachew, B., and Galmessa, A. (2018). I9putsoutputs Marketing System Efficiencies of Maize and Tomato Production of Bako Tibe and Guto Gida Districts of West Shewa and East Wollega Zones, Ethiopia. Dagnachew et al. (eds.), 2019. Oromia Agricultural research institute workshop proceeding on Adaptation and Generation of Agricultural Technologies, 26-29 June 2019, Addis Ababa, Ethiopia.

[31] Asrat, S., Yesuf, M., Carlsson, F., and Wale, E. (2010). Farmers' preferences for crop variety traits: Lessons for onfarm conservation and technology adoption. Ecological Economics, 69: 2394-2401.

[32] Witcombe, J. R., Joshi, K. D., Sthapit, B. R., and Virk, D. S. (2011). Impact of introduction of modern varieties on crop diversity. In Agrobiodiversity Management for Food Security, eds Wood D, Lenné JM (CABI, Wallingford), pp 87-98.

[33] Alemu, D. (2011). Farmer-based seed multiplication in the Ethiopian system: Approaches, priorities and performance. Future Agricultures Working Paper 036.

[34] Ayana, A., G. Borman, A. Subedi, F. Abay, H. Mohammed, K Nefo, N. Dechassa, and T. Dessalegn. 2013. Integrated seed sector development in Ethiopia: Local seed business development as an entrepreneurial model for communitybased seed production in Ethiopia. Addis Ababa, Ethiopia: ICRISAT.

[35] Mhlanga, B., Cheesman, S., Maasdorp, B., Muoni, T., Mabasa, S., and Mangosho, E. (2015). Weed community responses to rotations with cover crops in maize-based conservation agriculture systems of Zimbabwe. Crop Protection; 69: 1-8.

[36] Mkonda Y. M. and He, X. (2016). Production Trends of Food Crops: Opportunities, Challenges and Prospects to Improve Tanzanian Rural Livelihoods. Natural Resources and Conservation; 4 (4): 51-59.

[37] Umar, B. B. (2016). Seasonal Challenges and Opportunities for Smallholder Farmers in a Mining District of Zambia. Afr. J. Agric. Res.; 11 (13).

[38] Kiros, G. and Ashenafi, K. (2018). Challenges and Opportunities of Genetically Modified Crops Production; Future Perspectives in Ethiopia, Review. The Open Agriculture Journal; 12: 240-250.

[39] Denning, G., Kabambe, P., Sanchez, P., Malik, A., Flor, R., and Harawa, R. (2009). Input subsidies to improve household maize productivity in Malawi: toward an African Green Revolution (Essay). PLoS Biology; 7: e1000023.

[40] Stifel, D. and Minten, B. (2008). Isolation and agricultural productivity. Agricultural Economics 39, 1-15. Stoorvogel J. J. and Smaling E. M. A. 1990. Assessment of soil nutrient depletion in sub-Saharan Africa: 1983-2000. Wageningen University, Wageningen.

[41] Frelat, R., Lopez-Ridaura, S., Giller, K. E., Herrero, M., Douxchamps, S., and Djurfeldt, A. A. (2015). Drivers of household food availability in sub-Saharan Africa based on big data from small farms. Proceedings of the National Academy of Sciences of the United States of America; 113: $458-463$.

[42] Bezabih, E., Afari-Sefa, V., Fikadu, F. D., Amsalu, A., and Tesfaye, B. (2015) Characterization and assessment of vegetable production and marketing systems in the humid tropics of Ethiopia. Q. J. Inter. Agric. 2: 163-187.
[43] Djurfeldt, A. A. and Djurfeldt, G. (2013). Structural transformation and African households: Drivers of mobility within and between the farm and non-farm sectors for eight countries. Oxford Development Studies 41, 281-306.

[44] Amede, T., Descheemaeker, K., Everisto, M., Peden, D., Breugel, P. van, Awulachew, S. B., and Haileslassie A. (2011) Livestock-water productivity in the Nile Basin: Solutions for emerging challenges. In: A. M. Melesse (Ed.), Nile River Basin: Hydrology, climate and water use (pp. 297-320). New York: Springer Science plus Business Media B. V.

[45] Behnke, R. and Fitaweke, M. (2011). The contribution of livestock to the Ethiopian economy - Part II. IGAD Livestock Policy Initiative (LPI). Working Paper No. 02-11. Odessa Centre, Great Wolford, United Kingdom, 43p.

[46] Franke, A. C., Berkhout, E. D., Iwuafor, ENO., Nziguheba, G., Dercon, G., Vandeplas, I., and Diels, J. (2010a). Does croplivestock interaction lead to improved crop production in the savanna of West Africa? Exp Agric; 46 (4): 439-455.

[47] Harald, S., Paolo, C., Marco, D., Jose, LG-Mortos, David, S., and Loannis, S. A. (2014). Development of the EMAS Sectoral Reference Documents on Best Environmental Management Practice: JRC scientific \& policy report. doi: $10.2791 / 43526$.

[48] Zewdie, W. and Yoseph, M. (2014). Feed resources availability and livestock production in the central rift valley of Ethiopia. International Journal of Livestock Production; 5 (2): 30-35.

[49] Getahun, B. and Tegene, N. (218). Feed Resource Availability and their Nutrient Contribution for livestock Evaluated Using Feed Assessment Tool (FEAST) in Burie Zuria District, North Western Ethiopia. Agri Res \& Tech: Open Access J.; 17 (3): 556022 .

[50] Belay, D., Getachew, E., Azage, T., and Hegde, B. H. (2013). Farmers' perceived livestock production constraints in Ginchi watershed area: Result of participatory rural appraisal. International Journal of Livestock Production; 4 (8): 128-134.

[51] Samuel, M. (2014). Livestock Production Constrains Priorities and its Determinant Factors in Mixed Farming System of Southern Ethiopia. World Journal of Agricultural Sciences; 10 (4): 169-177.

[52] Emana, M. M., Ashenafi, M., and Getahun, A. (2017). Opportunity and Constraints of Livestock Feed Resources in Abol and Lare Districts of Gambella Region, Ethiopia. Nutrition and Food Science International Journal; 3 (4): 555620

[53] Ayele, S., Assegid, W., Jabbar, M. A., Ahmed, M. M., and Belachew, H. (2003). Livestock marketing in Ethiopia: A review of structure, performance and development initiatives. Socio-economics and Policy Research Working Paper 52. ILRI (International Livestock Research Institute), Nairobi, Kenya. 35 pp.

[54] Negassa, A., Shahidur, R., and Gebremedhin, B. (2011) Livestock Production and Marketing in Ethiopia. Ethiopia Strategy Support Program II, ESSP II Working Paper, pp: 2635 .

[55] Bekele, M., Mengistu, A. and Tamir, B. (2017). Livestock and feed water productivity in the mixed crop-livestock system. Animal, 11 (10): 1852-1860. 
[56] Alemayehu, W. and Abera, A. (2017). Assessment of beekeeping production system and constraints in Sude Woreda, Arsi Zone Oromia Ethiopia. Journal of Horticulture and Forestry; 9 (12): 109-114.

[57] Kenesa, T. (2018). Status of Beekeeping in Ethiopia- A Review. Dairy and Vet Sci J.; 8 (4): 555743.

[58] Taye, B. and Marco, V. (2014). Assessment of constraints and opportunities of honey production in Wonchi District South West Shewa Zone of Oromia, Ethiopia. American Journal of Research Communication; 2 (10): 342-353.

[59] Birhanu, T. A. (2016). Constraints and Opportunities of Honeybee Production and Honey Marketing Systems: A Case of Guji and Borena Zone of Oromia State". EC Agriculture; 3 (3): 635-645.

[60] Sahle, H., Enbiyale G., and Negash, A. (2018). Assessment of honey production system, constraints and opportunities in Ethiopia. Pharm Pharmacol Int J.; 6 (1): 42-47.

[61] Tsegamariam, D. and Tadele, A. (2019). Natural Resource Use, Misuse, Strategy, Policy to Regeneration and Conservation in Ethiopia. In Case of Soil and Water. Sci J Biol \& Life Sci.; 1 (1): SJBLS. MS. ID. 000501.

[62] Gebru, B. M., Wang, S. W., Kim, S. J., and Lee, W.-K. (2019) Socio-Ecological Niche and Factors Affecting Agroforestry Practice Adoption in Different Agro-ecologies of Southern Tigray, Ethiopia. Sustainability, 11, 3729.

[63] Hurni, H, Berhe, W. A, Chadhokar, P, Daniel, D, Gete, Z, Grunder, M, and Kassaye, G. (2016). Soil and Water Conservation in Ethiopia: Guidelines for Development Agents. Second revised edition. Bern, Switzerland: Centre for Development and Environment (CDE), University of Bern, with Bern Open Publishing (BOP). 134 pp.

[64] Tsegaye, M. and Abiy, G. M. (2014). Review on Overall Status of Soil and Water Conservation System and Its Constraints in Different Agro Ecology of Southern Ethiopia Genene. Journal of Natural Sciences Research; 4 (7): 59-69.
[65] Dorosh, P. and Rashid, S. (Eds.). (2013). Food and agriculture in Ethiopia: Progress and policy challenges. University of Pennsylvania Press.

[66] Headey, D., Dereje, M. and Taffesse, A. S. (2014). Land constraints and agricultural intensification in Ethiopia: A village-level analysis of high-potential areas. Food policy; 48: 129-141.

[67] Berhanu, G., Hoe, K. D., and Azage, T. (2006). Commercialization of Ethiopian agriculture: Extension service from input supplier to knowledge broker and facilitator. IPMS (Improving Productivity and Market Success) of Ethiopian farmers' project working paper 1. ILRI (International Livestock Research Institute), Nairobi, Kenya. 36p.

[68] Melesse, B. (2018). A Review on Factors Affecting Adoption of Agricultural New Technologies in Ethiopia. J Agri Sci Food Res; 9 (3): 226.

[69] Manfre, C. and Nordehn, C. (2013). Exploring the promise of information and communication technologies for women farmers in Kenya. Cultural practice, LLC, MEAS Case Study, 4.

[70] Ataklite, B. (2016). Agricultural Transformation in Ethiopia: State Policy and Smallholder Farming: www.eedboos.net

[71] Matsumoto T and Yamano T. (2011). The Impacts of Fertilizer Credit on Crop Production and Income in Ethiopia. In Emerging Development of Agriculture in East Africa (pp. 59-72). Springer, Dordrecht.

[72] Awotide, B. A., Abdoulaye, T., Alene, A. D., and Manyong, V. M. (2015). Impact of Access to Credit on Agricultural Productivity: Evidence from Smallholder Cassava Farmers in Nigeria. DOI: 10.22004/ag.ecom.2069.

[73] Peter, N., Shedrack, W. and John, H. (2015). First Mile Transport Challenges for Smallholder Tomato Farmers, Kilolo District Tanzania. IFRTD, Kenya. 